\title{
Zaburzenia zmysłu węchu
}

\section{Smell dysfunction}

\author{
Piotr Rapiejko', Agnieszka Lipiec ${ }^{2}$ \\ ${ }^{1}$ Klinika Otolaryngologii i Onkologii Laryngologicznej z Klinicznym Oddziałem Chirurgii \\ Czaszkowo-Szczękowo-Twarzowej, Wojskowy Instytut Medyczny w Warszawie \\ ${ }^{2}$ Zakład Profilaktyki Zagrożeń Środowiskowych i Alergologii, Warszawski Uniwersytet Medyczny
}

\begin{abstract}
Streszczenie:
Węch jest podstawowym zmysłem zarówno u ludzi, jak i u zwierząt. Pozwala kręgowcom i innym organizmom wyposażonym w receptory węchowe rozpoznawać pożywienie, niebezpieczeństwo i dostarcza zmysłowej przyjemności. Zaburzenia lub utrata zmysłu węchu występują w schorzeniach, którym towarzyszy upośledzona drożność nosa, takich jak: przewlekłe zapalenie zatok przynosowych, przewlekłe zapalenie zatok przynosowych z polipami nosa, alergiczny nieżyt nosa, infekcja dróg oddechowych, w tym ostre zapalenie zatok przynosowych. W przypadku zapalenia zatok przynosowych zaburzenia węchu są jednym z czterech głównych objawów choroby. Zaburzenia węchu mogą być również wywołane przez uszkodzenie neuronu węchowego, np. w przebiegu infekcji wirusowej. Utrata węchu i/lub smaku zgłaszana przez chorych na COVID-19 ma istotne znaczenie kliniczne; ułatwia jak najwcześniejszą identyfikację zakażonych do izolacji, jeśli dostęp do badań jest ograniczony, oraz ułatwia kwalifikację do ukierunkowanych testów. W leczeniu zaburzeń i utraty węchu wywołanych przez upośledzenie drożności nosa (lub towarzyszących chorobom przebiegającym z upośledzeniem drożności nosa) stosuje się nowoczesne glikokortykosteroidy donosowe.

\section{Abstract:}

The sense of smell is a primal sense for humans as well as animals. Smell allows vertebrates and other organisms with olfactory receptors to identify food, predators and provides both sensual pleasures as well as warnings of danger. Dysfunction or loss of sense of smell occurs in diseases accompanied by impaired nasal patency such as chronic rhinosinusitis, chronic rhinosinusitis with nasal polyps, allergic rhinitis, respiratory infections including acute rhinosinusitis. In the case of rhinosinusitis, olfactory disturbances are one of the four main symptoms of the disease. Olfactory dysfunction may also be caused by damage to the olfactory neuron, e.g. during a viral infection. The loss of smell and/or taste reported by patients with COVID-19 is of major clinical importance; it facilitates the earliest possible identification of the infected for isolation, if access to testing is limited, and facilitates qualification for targeted testing. Modern intranasal corticosteroids are used in the treatment of disorders and loss of smell caused by impaired nasal patency (or accompanying diseases with impaired nasal patency).
\end{abstract}

Słowa kluczowe: zaburzenia zmysłu węchu, zapalenie zatok przynosowych, COVID-19

Key words: smell dysfunction, rhinosinusitis, COVID-19

\section{Wstęp}

Prawidłowo funkcjonujący zmysł węchu rzadko jest obiektem zainteresowania lekarzy i pacjentów. To najbardziej niedoceniany, a jednocześnie zagadkowy zmysł. Zainteresowanie zmysłem węchu znacząco wzrosło po przyznaniu w 2004 r. Nagrody Nobla Richardowi Axelowi i Lindzie B. Buck za badania nad jego receptorami [1].

Utrata lub upośledzenie węchu może być procesem wtórnym w różnych schorzeniach (neurologicz- nych, laryngologicznych i metabolicznych) lub też ich podstawowym objawem. Zaburzenia zmysłu węchu są jednym $z$ czterech podstawowych objawów u chorych z przewlekłym zapaleniem zatok przynosowych (z polipami i bez polipów nosa). Czasową utratę lub upośledzenie węchu obserwuje się również u chorych w przebiegu infekcji przeziębieniowych górnych dróg oddechowych i grypy. W 2020 r. w związku z pandemią COVID-19 znacząco wzrosło zainteresowanie lekarzy i chorych zmysłem węchu. Utrata węchu i/lub smaku 
została uznana przez Swiatową Organizację Zdrowia (WHO, World Health Organization) za jeden z charakterystycznych objawów zakażenia wirusem SARS-CoV-2 [2]. Należy jednak pamiętać, że upośledzenie węchu następuje też po ekspozycji na związki toksyczne, dym tytoniowy, leki o działaniu toksycznym na nerwy węchowe oraz u osób nałogowo zażywających kokainę.

\section{Budowa narządu zmysłu węchu}

W obrębie stropu jamy nosowej i na przednim końcu małżowiny nosowej górnej oraz w górnej części przegrody nosa występuje nabłonek węchowy (olfactory epithelium). U ludzi zajmuje on powierzchnię ok. 1-3 $\mathrm{cm}^{2}$ - wielokrotnie mniejszą niż u zwierząt. Nabłonek węchowy jest znacznie grubszy od nabłonka oddechowego. Tworzą go: komórki nerwowo-zmysłowe węchowe, komórki podstawne oraz komórki podporowe. Komórka nerwowo-zmysłowa węchowa to komórka nerwowa o dwóch wypustkach. Jedna z nich jest pęcherzykiem pokrytym włoskami węchowymi, wystającymi spomiędzy komórek podstawnych nad powierzchnię nabłonka [3]. Druga wypustka przewodzi impulsy od ciała komórki - spełnia funkcję aksonu. Komórki nerwowo-zmysłowe węchowe są neuronami o podwójnej funkcji; to jednocześnie chemoreceptory i komórki przewodzące impulsy. Komórki węchowe stykają się bezpośrednio ze światem zewnętrznym organizmu. To jedyne miejsce w organizmie człowieka, w którym komórki nerwowe bez pośrednictwa odbierają bodźce ze środowiska zewnętrznego. W warunkach fizjologicznych nabłonek węchowy pokrywa warstwa śluzu, która jest jedyną przegrodą oddzielającą komórki nerwowe od świata zewnętrznego. $\mathrm{Z}$ powodu takiego położenia komórki węchowe są narażone na działanie różnych czynników, np. wirusów i substancji chemicznych, w tym leków, które mogą przez nie docierać do ośrodkowego układu nerwowego (OUN).

W najnowszych opracowaniach warstwę śluzu pokrywającą błonę śluzową nosa, wraz z zawartymi w niej białkami wiążącymi substancje zapachowe, uważa się za integralną część narządu zmysłu węchu i określa jako jednostkę okołoreceptoryczną. Z fizjologicznego punktu widzenia warstwa śluzu pokrywająca błonę śluzową jest niezbędna do prawidłowego funkcjonowania zmysłu węchu - w śluzie bowiem rozpuszczają się występujące w powietrzu substancje zapachowe. Komórki receptoryczne są umieszczone na rusztowaniu utworzonym przez komórki podporowe i podstawne zrębu epitelium węchowego. Komórki podporowe nie tylko stanowią elementy rusztowania, lecz także czynnie wydzielają mukopolisacharydy oraz odgrywają rolę izolacyjną, oddzielając komórki receptoryczne od siebie. Współpracują też przy przenoszeniu molekuł przez nabłonek węchowy i regulują w jego obrębie stosunki płynowe. Komórki podporowe wydzielają cytochrom P450, degradując i usuwając zbędne cząstki wonne oraz substancje potencjalnie toksyczne. To z komórek podstawnych mogą się regenerować komórki receptoryczne. Aksony ok. 20 komórek węchowych tworzą nić węchową wnikającą do jamy czaszki przez otwory w blaszce sitowej (papierowatej). To miejsce jest krytyczne dla ewentualnego przerwania ciągłości struktur nerwowych zmysłu węchu. W przypadku silnego urazu nosa może dojść do przerwania (ścięcia) zakończeń nerwowych przechodzących przez blaszkę sitową. Aksony kończą się synapsami w opuszce węchowej na dendrytach komórek mitralnych tworzących kłębuszek węchowy. Komórki te są drugim neuronem czuciowym i oddają aksony przez pasmo węchowe do okolicy trójkąta węchowego oraz istoty dziurkowanej przedniej.

Trzecie neurony czuciowe odbierające impulsy wysyłane przez komórki mitralne występują w strukturach zaliczanych do węchomózgowia. Neurony te znajdują się w korze mózgu w sąsiedztwie trójkąta węchowego, w zakręcie hipokampu, w zakręcie gruszkowatym stanowiącym część haka zakrętu hipokampu oraz w guzku węchowym, jądrze węchowym przednim i ciele migdałowatym [4]. Unerwienie czuciowe odbiera wrażenia dotykowe i bólowe. Te ostatnie mogą imitować wrażenia węchowe u osób, które utraciły węch. Dzieje się tak, kiedy docierają do nich substancje zapachowe drażniące także receptory bólu, np. zapach pieprzu [3].

\section{Działanie zmysłu węchu}

Substancje zapachowe zawarte w powietrzu są wprowadzane do jamy nosa w sposób czynny w trakcie wdechu lub węszenia. Osadzają się na pokrywającej błonę śluzową jam nosa warstwie śluzu i ulegają zagęszczeniu. Rozpuszczają się w warstwie hydrofobowej śluzu i łączą z obecnymi w nim białkami wiążącymi substancję zapachową (OBP, odorant-binding protein). Takie kompleksy - substancja zapachowa + białko OBP łączą się z receptorami, które znajdują się na rzęskach węchowych w błonie śluzowej pokrywającej dolną powierzchnię blaszki sitowej oraz przyległe fragmenty przegrody i ściany bocznej w obrębie małżowiny nosowej górnej [3].

Aktywacja receptora odbywa się poprzez przyłączenie do niego liganda (cząsteczki zapachowej) 
i prowadzi do aktywacji błonowego enzymu, cyklazy adenylanowej, za pośrednictwem jednej z podjednostek białka G. Aktywność cyklazy adenylanowej przyczynia się do zwiększenia w komórce stężenia cząsteczek cyklicznego adenozynomonofosforanu (cAMP, cyclic adenosine monophosphate) oraz otwarcia zależnych od niego błonowych kanałów jonowych. Otwarcie kanałów powoduje napływ do komórki kationów sodowych i w konsekwencji powstanie potencjału czynnościowego w neuronie węchowym [1, 3]. Po związaniu substancji zapachowych $\mathrm{z}$ receptorem białkowym rzęsek pierwszego neuronu następuje usuwanie zbędnych molekuł poprzez: odpływ śluzu, degradację enzymatyczną w komórkach podporowych i przenikanie do przestrzeni międzykomórkowej oraz do układu naczyniowego $[1,3]$.

Pobudzone komórki wysyłają sygnały do opuszki węchowej i synaps w obrębie kłębuszków węchowych (na dendrytach komórek mitralnych lub pędzelkowatych). Aksony komórek mitralnych i pędzelkowatych tworzą pasmo węchowe [3]. Komórki mitralne i pędzelkowate wysyłają projekcję do kory węchowej przez pasmo węchowe.

Kora węchowa jest trójwarstwową korą dawną (zwaną też prakorą) przypominającą korę przodomózgowia niższych kręgowców. To jedyna kora, która otrzymuje wejście sensoryczne bezpośrednio (a nie drogą poprzez wzgórze). Projekcja kory węchowej do podwzgórza i ciała migdałowatego łączy się z emocjonalnym odbiorem zapachów [3, 5]. Droga do hipokampu wiąże się ściśle z pamięcią zapachów i ze związanymi z nimi emocjami, wspomnieniami i odruchami. Wejście sygnałów przez wzgórze do zakrętów czołowych płata czołowego pośredniczy w świadomej percepcji zapachów. Tym samym węch, jako „stary, pierwotny zmysł", nie poddaje się naszej kontroli. Reagujemy odruchowo na zapachy, a dopiero gdy sygnały przejdą przez wzgórze, możemy dokonać świadomej analizy zapachu. To odruchowe działanie może zostać wykorzystane w obiektywnych badaniach zmysłu węchu [3, 5-8]. Bliskie więzi anatomiczne narządu węchu i ciała migdałowatego, hipokampu oraz podwzgórza pozwalają zrozumieć ścisły związek pomiędzy percepcją zapachu a funkcjami poznawczymi, takimi jak: pamięć, motywacja oraz pobudzenie seksualne [3].

\section{Znaczenie zmysłu węchu}

Znaczenie narządu węchu u człowieka wyrażone jest w:

- ostrzeganiu o niebezpiecznych substancjach w otoczeniu, zagrażających życiu i zdrowiu (dym, gazy trujące)
- lokalizacji źródła niebezpiecznego lub nieprzyjemnego zapachu

- doborze właściwych pokarmów (ze zwróceniem uwagi na ich jakość i świeżość)

- utrzymywaniu na odpowiednim poziomie fizjologicznego łaknienia

- udziale w procesie wydzielania śliny i soku żołądkowego pod wpływem przyjemnych zapachów żywności

- udziale w percepcji wrażeń smakowych

- tworzeniu uczucia pełnego komfortu psychicznego

- wpływie na jakość życia dzięki odczuwaniu i ocenie zapachów otaczającej przyrody

- źródle przeżyć i odczuć estetycznych, zachowań emocjonalnych i seksualnych

- samokontroli stanu higienicznego (zapach potu itd.)

- odbiorze istotnych informacji społecznych (rozpoznanie matki, dziecka, odruch ssania) $[3,9,10]$.

\section{Substancje zapachowe}

Substancje zapachowe można podzielić na trzy grupy [6]:

- związki pobudzające przede wszystkim nerw węchowy: kawa, herbata, olejek anyżowy, wanilia.

- związki pobudzające nerw węchowy i gałązki końcowe nerwu trójdzielnego w błonie śluzowej nosa: kamfora, amoniak, eter, roztwory alkoholowe, olej miętowy, olejek cytrynowy

- związki pobudzające nerw węchowy i gałązki końcowe nerwu językowo-gardłowego na podstawie języka (chloroform - odczucie smaku słodkiego, pirydyna - odczucie goryczy).

\section{Metody badania zmysłu węchu}

W codziennej praktyce i w badaniach klinicznych jest stosowanych wiele metod badania narządu węchu. Badanie może mieć charakter jakościowy lub ilościowy, może być subiektywne bądź obiektywne. Testy jakościowe są proste, tanie i mało czasochłonne. Opierając się na identyfikacji lub dyskryminacji pospolitych, znanych badanemu substancji zapachowych. Badania ilościowe wymagają zastosowania specjalistycznych urządzeń - olfaktometrów [6]. Z uwagi na pandemię COVID-19 większą rolę odgrywają obecnie wywiad oraz badania, które chory może przeprowadzić samodzielnie w czasie telekonsultacji; kwestionariusze samooceny, wizualna skala analogowa (VAS, visual analogue scale), subiektywna samoocena „domowa”. 


\section{Wywiad}

Podstawowe znaczenie w diagnostyce zaburzeń zmysłu węchu ma badanie podmiotowe. Spontanicznie przekazana przez pacjenta informacja o zauważonych przez niego lub przez jego otoczenie zaburzeniach zmysłu węchu jest bardzo cenna. W większości przypadków chorzy nie zgłaszają jednak lekarzowi spontanicznie faktu występowania zaburzeń zmysłu węchu, bagatelizując ten objaw. Pacjenci ze schorzeniami przewlekłymi, np. przewlekłym zapaleniem zatok przynosowych z polipami nosa, u których zaburzenia węchu występują od dłuższego czasu, „przyzwyczajają się" do braku prawidłowo funkcjonującego węchu i również nie zgłaszają tego w trakcie zbierania wywiadu [6]. W związku z licznymi doniesieniami medialnymi dotyczącymi zaburzeń węchu w przebiegu COVID-19 należy się liczyć z częstszym zgłaszaniem przez chorych zaburzeń w tym zakresie.

\section{Badania jakościowe}

UPSIT (The University of Pennsylvania Identification Test) to badanie polegające na zdrapaniu mikrokapsułki z substancją zapachową i rozpoznaniu zapachu. Może być przeprowadzone jako badanie identyfikacji zapachu (pytamy chorego, jaki zapach odczuwa) lub dyskryminacji zapachu (wymieniamy trzy lub cztery wersje odpowiedzi i prosimy pacjenta o wskazanie prawidłowej). Metoda scratch and sniff polega na zliczeniu prawidłowo rozpoznanych substancji zapachowych spośród wielu poddanych badaniu (zwykle jest ich kilkanaście do kilkudziesięciu) [6].

Test pisakowy (sniff in sticks) - to badanie polegające na naniesieniu na kartkę papieru substancji zapachowej. Do testowania można używać różnych substancji zapachowych umieszczonych $\mathrm{w}$ pisaku: aromatu waniliowego, aromatu cytrynowego, olejku miętowego, olejku różanego, rozpuszczalnika do farb nitro, nawaniacza gazu ziemnego, amoniaku. Badanie testem pisakowym jest badaniem orientacyjnym i może służyć jedynie jako badanie przesiewowe. W przypadku stwierdzenia nieprawidłowości w powyższym teście należy rozważyć przeprowadzenie pełnego badania olfaktometrycznego [6, 7].

Testy jakościowe są bardzo proste do wykonania, tanie i pozwalają na szybkie wykonanie badania przez lekarza w każdym gabinecie.

Do badania symulacji anosmii może służyć metoda Gutticha, polegająca na podaniu na język esencji. Pacjent $\mathrm{z}$ anosmią będzie odczuwał czystą wodę. Chory z prawidłowym węchem i smakiem odpowie, że odczuwa aromat esencji, bowiem przedostaje się on do jamy nosowej przez nozdrza tylne [6].

\section{Badanie ilościowe (badanie poziomu odczucia zapachu - threshold)}

W celu oceny stopnia upośledzenia zmysłu węchu oraz oceny postępu terapii wykonuje się określanie minimalnej ilości powietrza nasyconego substancją zapachową, która powoduje odczucie zapachu (POZ, próg odczucia zapachu) oraz ilościowe określenie minimalnej ilości powietrza nasyconego substancją zapachową, przy której badany mógł zidentyfikować zapach (PIZ, próg identyfikacji zapachu). Najczęściej jest stosowana metoda podmuchowa Elsberga-Levy'ego, polegająca na podaniu do nozdrza pacjenta powietrza z kolby, w której znajduje się badana substancja zapachowa. Wynik zapisywany jest jako najmniejsza objętość powietrza, którą należało wprowadzić do nozdrza chorego, aby odczuł (POZ) i zidentyfikował zapach (PIZ). Metoda jest bardziej czasochłonna od testów jakościowych i wymaga wyposażenia gabinetu w specjalistyczny sprzęt [6].

\section{Olfaktometria obiektywna}

Metody olfaktometrii obiektywnej opierają się na rejestracji reakcji odruchowych, np. szerokości źrenicy (odruch węchowo-źreniczy), oporności elektrycznej skóry (reakcja skórno-galwaniczna), rytmu oddechowego czy częstości tętna. Standaryzacja metod obiektywnych badania zmysłu węchu nadal sprawia wiele trudności [6].

\section{Zaburzenia węchu}

Przyczyną upośledzenia lub braku węchu mogą być zarówno zaburzenia typu przewodzenia bodźca, jak i zaburzenia neuronu zapachowego $[3,6]$.

Do najczęstszych zaburzeń typu przewodzenia należą [6]:

- niedrożność jam nosa w przebiegu:

- polipów nosa

- skrzywienia przegrody nosa

- przerostu małżowin nosowych

- zapalenia alergicznego błony śluzowej nosa

- zapalenia zatok przynosowych z zajęciem części węchowej błony śluzowej nosa

- zmiany w obrębie błony śluzowej jam nosa (np. zaburzenia wydzielania lub składu śluzu)

- wady rozwojowe i zmiany pourazowe

- guzy nosa i nosogardła.

W codziennej praktyce spotykamy się przede wszystkim z upośledzeniem węchu spowodowanym zaburzeniami kontaktu substancji zapachowych z zakończeniami nerwów węchowych. Najczęstszymi przyczynami takich zaburzeń są [6]: 
- upośledzenie drożności nosa w obrębie przewodu nosowego górnego i środkowego

- obecność patologicznej, gęstej lub zaschniętej wydzieliny pokrywającej nabłonek węchowy i uniemożliwiającej kontakt substancji zapachowych z powietrza z nabłonkiem węchowym

- zaburzenia składu śluzu (np. zmniejszenie stężenia białka wiążącego substancje zapachowe)

- uszkodzenie błony śluzowej nosa w okolicy węchowej.

Pojawienie się zaburzeń węchu u chorych leczonych z powodu polipów nosa traktujemy jako objaw postępu choroby i sygnał do konieczności zwiększenia dawki glikokortykosteroidów podawanych donosowo. Zaburzenia węchu w przebiegu schorzeń alergicznych są zwykle przemijające i ograniczone do ostrej fazy reakcji alergicznej i stanowią przede wszystkim skutek obrzęku błony śluzowej nosa w przewodzie nosowym górnym i środkowym. U chorych z przewlekłym zapaleniem zatok może dojść do trwałych zaburzeń węchu o mieszanej etiologii - zarówno związanych z obrzękiem błony śluzowej nosa, jak i z zaburzeniami składu śluzu oraz z uszkodzeniem błony śluzowej i nabłonka węchowego.

Przyczyny zaburzeń węchu leżące po stronie neuronu węchowego to przede wszystkim [6]:

- urazy czaszki, szczególnie ze złamaniem podstawy przedniego dołu czaszki (przerwanie nitek węchowych, stłuczenie opuszki)

- uszkodzenie opuszki w mechanizmie przeciwuderzenia (np. upadek na tyłogłowie)

- ostre zakażenia wirusowe (w tym SARS-CoV-2)

- zmiany zapalne (zapalenie opon mózgowych, kiła)

- krwotok podpajęczynówkowy

- guzy przedniego dołu czaszki (oponiak rynienki nerwowej, glejak opuszki, glejak płata czołowego, tętniak)

- urazy jatrogenne

- przewlekły zanikowy nieżyt nosa

- ekspozycja na związki toksyczne, pyły nieorganiczne, dym tytoniowy

- zaburzenia hormonalne

- cukrzyca

- nałogowe zażywanie kokainy, stosowanie leków o działaniu toksycznym na nerwy węchowe (np. aminoglikozydów)

- choroba Alzheimera

- choroba Parkinsona

- zaburzenia związane z wiekiem podeszłym (presbyosmia).

\section{Najczęstsze zaburzenia węchu to:}

- anosmia - brak wrażeń węchowych/utrata węchu

- hyposmia - upośledzenie węchu

- parosmia, kakosmia - odczuwanie odmiennych, nienormalnych doznań węchowych (halucynacje węchowe); powodem mogą być zmiany - podrażnienie (np. przez guz) lub blizna glejowa w obrębie hipokampu, jądra migdałowatego lub podstawy płata skroniowego [6]

- hyperosmia - nadwrażliwość węchowa; jest często przejawem somatyzacji depresji.

\section{Zaburzenia węchu i smaku w przebiegu COVID-19}

Utrata węchu i/lub smaku zgłaszana przez chorych z COVID-19 ma istotne znaczenie kliniczne; ułatwia jak najwcześniejszą identyfikację zakażonych do izolacji, jeśli dostęp do badań jest ograniczony, oraz ułatwia kwalifikację do ukierunkowanych testów.

Częstość, z jaką objaw ten występuje w przebiegu COVID-19, wynika z licznych obserwacji. Metaanaliza przeprowadzona przez zespół Borsetto i wsp. [11] uwzględniła 18 opublikowanych badań obejmujących 3563 pacjentów, u których choroba przebiegała $\mathrm{z}$ różnym stopniem nasilenia. Średnia częstość występowania zgłaszanych przez pacjentów zaburzeń węchu i/lub smaku w przebiegu zakażenia wirusem SARS-CoV-2 wyniosła 47\%. Utrata węchu i smaku poprzedzała wystąpienie innych objawów zakażenia w 20\% przypadków, a współwystępowała z innymi w 28\% przypadków. Wykazano różnice w częstości, zależne od stopnia nasilenia choroby; od 31\% przy ciężkim przebiegu COVID-19 do 67\% w przebiegu łagodnym, do umiarkowanego [11].

Również z wieloośrodkowego badania zespołu Izquierdo-Domínguez i wsp. [12], przeprowadzonego na łącznej grupie 989 pacjentów 15 uniwersyteckich szpitali klinicznych w Hiszpanii, wynika, że zaburzenia węchu i smaku występują częściej u osób, które z powodu łagodnego przebiegu COVID-19 nie wymagają hospitalizacji. Ocena stopnia utraty węchu i smaku w badanej grupie wykazała, iż silną utratę węchu zgłaszało $53,7 \%$ badanych, silną utratę smaku - 52,2\%, zaś oba zmysły były upośledzone w ponad 90\% przypadków [12]. Metaanaliza zespołu Agyemana i wsp. [13] z kliniki Mayo objęła 24 badania z danymi dotyczącymi 8438 pacjentów z zakażeniem COVID-19 z 13 krajów. Odsetek chorych prezentujących zaburzenia węchu wynosił $41,0 \%$, a zaburzenia smaku - 38,2\%. Wzrost średniej wieku chorych korelował z niższą częstością zaburzeń smaku i węchu, podobnie jak w badaniu Izquierdo-Domínguez i wsp. [12]. Wyższą częstość odnotowano przy wykorzystaniu 
obiektywnych metod oceny tych zaburzeń niż przy wykorzystaniu własnych zgłoszeń pacjentów [13].

Najobszerniejsza metaanaliza Saniasiai i wsp. [14], która objęła 83 opublikowane badania z danymi 27492 pacjentów, wykazała, iż zaburzenia węchu dotyczą 47,85\% chorych w przebiegu zakażenia SARS-CoV-2, przy czym anosmia rozwija się u 35,39\%, hyposmia - u 36,15\%, a dysosmia - u 2,53\%. Natomiast przegląd systematyczny 40 badań (10 228 chorych) - przeprowadzony przez zespół Amorim Dos Santos i wsp. [15] wykazał, iż zaburzenia smaku dotyczą $45 \%$ pacjentów z COVID-19, przy czym ageuzja (brak smaku) dotyczy 24\%, hypogeuzja (upośledzenie smaku) - 35\%, a dysgeuzja (zaburzenie smaku) - 38\% chorych.

Mechanizm prowadzący do zaburzeń węchu i smaku w przebiegu COVID-19 wynika prawdopodobnie $\mathrm{z}$ tego, iż nabłonek węchowy jamy nosowej jest miejscem zwiększonego wiązania wirusa SARS-CoV-2. Komórki podporowe, które utrzymują integralność węchowych neuronów czuciowych, charakteryzuje wysoka ekspresja receptorów komórkowych
ACE-2 (enzymu konwertującego angiotensynę 2) oraz TMPRSS2 (przezbłonowej proteazy serynowej 2), umożliwiających wiązanie i wnikanie wirusa SARS-CoV-2 do komórek. Uszkodzenie tych właśnie komórek leży najprawdopodobniej u podstaw zaburzeń węchu i smaku w przebiegu zakażenia SARS-CoV-2 [16]. Postulowany jako współistniejący, mechanizm opiera się na neurotropowych właściwościach koronawirusów. Proponowana jest tu rola stanowiącego drugą zidentyfikowaną drogę wnikania wirusa SARS-CoV-2, receptora NRP1, którego ekspresja na węchowych neuronach czuciowych może uławiać bezpośrednie uszkodzenie i transport aksonalny do opuszki węchowej [17].

Średni czas utrzymywania się zaburzeń węchu w przebiegu zakażenia SARS-CoV-2 wynosi 9,03 dnia $\pm 1,32$, a zaburzeń smaku 12,64 dnia $\pm 2,51$, jak wynika $\mathrm{z}$ metaanalizy zespołu von Barthelda i wsp. [18] 42 badań przeprowadzonych u 23353 chorych z COVID-19. Zespół Izquierdo-Domínguez i wsp. [12] odnotował wysoki wskaźnik samoistnego powrotu węchu i smaku w ciągu 2 tygodni [12]. Jednakże ok.

Rycina 1. Schemat postępowania w przypadku stwierdzenia utraty węchu w trakcie pandemii COVID-19 wedtug ENT UK.

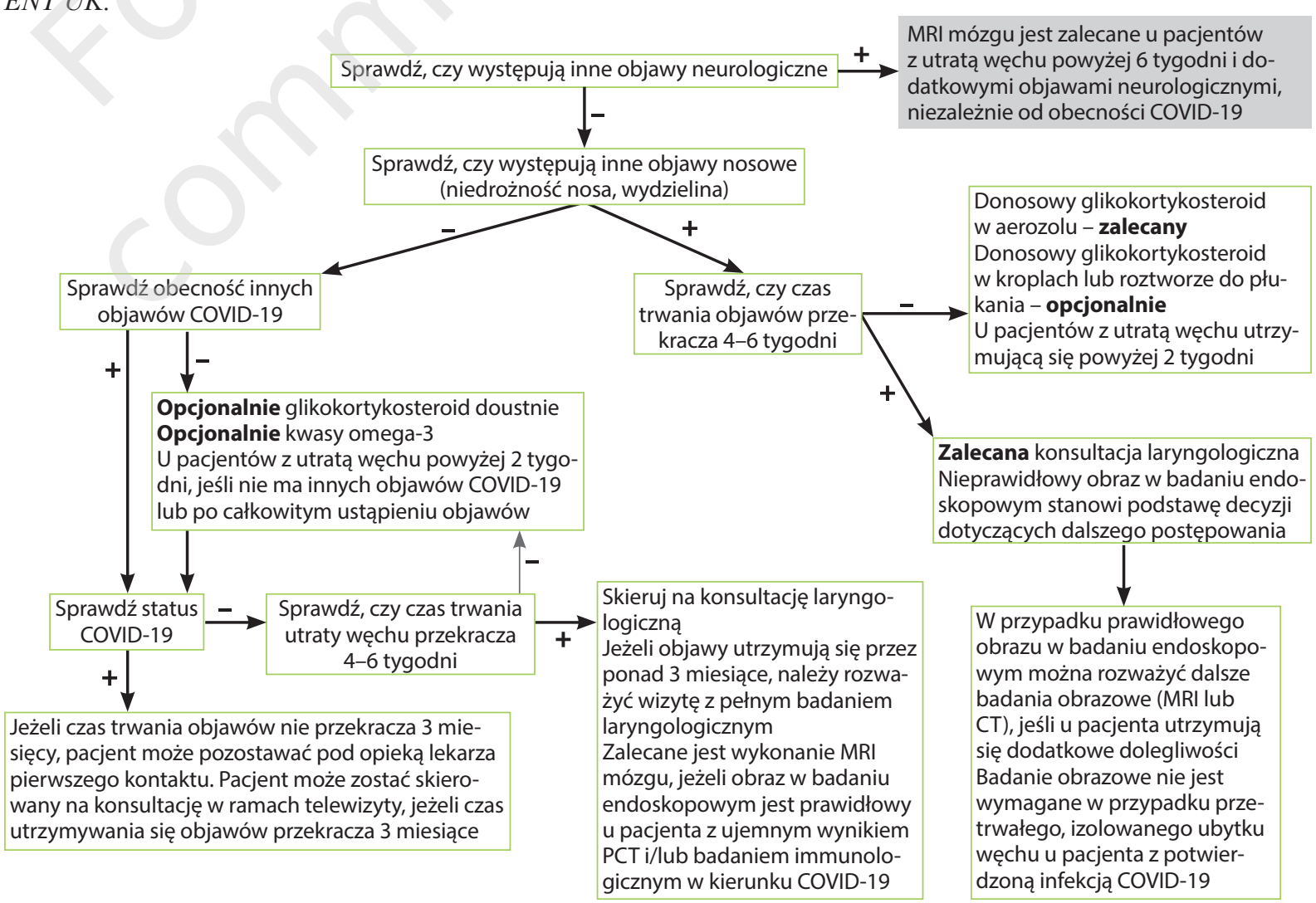

Opcjonalnie oznacza, że konsensus grupy ekspertów Brytyjskiego Towarzystwa Rynologicznego został osiągnięty przy progu na poziomie 60\%, a nie 70\%, podkreślając ciągłą niepewność dotyczącą zastosowania.

Obecność COVID-19 powinna być ustalona poprzez wywiad/badanie PCR/badanie immunologiczne u wszystkich pacjentów, jeśli to możliwe. Trening węchowy zalecany jest pacjentom, u których utrata węchu trwa powyżej 2 tygodni. 
$10 \%$ chorych nie odzyskuje węchu i smaku po 4-6 tygodniach od ich utraty [19]. Brytyjskie Towarzystwo Rynologiczne opublikowało zalecenia dotyczące postępowania w przypadku wystąpienia utraty węchu w trakcie pandemii COVID-19. Powyższe zalecenia prezentuje rycina 1 [19].

\section{Podsumowanie}

- Upośledzenie lub utrata węchu jest ważnym objawem wielu chorób błony śluzowej nosa i zatok przynosowych.

- Pytanie o występowanie zaburzeń węchu powinno być rutynowo zadawane każdemu choremu zgłaszającemu dolegliwości z zakresu nosa i zatok przynosowych oraz wszystkim chorym $\mathrm{w}$ trakcie infekcji górnych dróg oddechowych.

- W terapii zaburzeń i utraty węchu jest zalecane stosowanie nowoczesnych, donosowych glikokortykosteroidów - leczenie przewlekłe do ustąpienia dolegliwości.

- Brak poprawy funkcjonowania zmysłu węchu po 3-miesięcznej terapii donosowymi glikokortykosteroidami jest wskazaniem do pogłębionej diagnostyki rynologicznej i neurologicznej.

\section{Piśmiennictwo}

1. Buck LB. Olfactory receptors and odor coding in mammals. Nutr Rev. 2004; 62(11):184-8.

2. https://www.who.int/health-topics/coronavirus\#tab=tab_3 (access: 29.11.2020).

3. Rapiejko P. Zaburzenia zmyshu węchu. Medical Education, Warszawa 2016.

4. Ciszek B. Anatomia nosa i zatok przynosowych. In: Niemczyk K, Jurkiewicz D, Składzień J et al. (ed). Otolaryngologia kliniczna. Vol 2. Medipage, Warszawa 2015: 313-9.

5. Rapiejko P. Zmyst węchu. Alergoprofil. 2006; 4(7): 4-10.

6. Rapiejko P. Badanie zmystu węchu. In: Niemczyk K, Jurkiewicz D, Składzień J et al (ed). Otolaryngologia kliniczna. Vol 1. Medipage, Warszawa 2014: 121-3.

7. Rapiejko P, Jurkiewicz D. Badanie zmystu węchu testem pisakowym u chorych z ostrym zapaleniem zatok przynosowych. Alergoprofil. 2009; 5(1): 11-4.

8. Rapiejko P. Znaczenie badania zmystu węchu $w$ diagnostyce i terapii chorób blony śluzowej nosa. Wydawnictwo Klinika Otolaryngologii WIM, Warszawa 2009.

9. Huumel T, Welge-Lussen A (ed). Taste and smell. Karger AG, Basel 2006

10. Jurkiewicz D, Rapiejko P. Fizjologia nosa i zatok przynosowych. In: Niemczyk K, Jurkiewicz D, Sktadzień J et al (ed).
Otolaryngologia kliniczna. Vol 2. Medipage, Warszawa 2015: 319-24.

11. Borsetto D, Hopkins C, Philips V et al. Self-reported alteration of sense of smell or taste in patients with COVID-19: a systematic review and meta-analysis on 3563 patients. Rhinology. 2020; 58(5): 430-6. https://doi.org/10.4193/ Rhin20.185.

12. Izquierdo-Domínguez A, Rojas-Lechuga MJ, Chiesa-Estomba Cet al. Smell and taste dysfunction in COVID-19 are associated with younger age in ambulatory settings: A multicenter cross-sectional study. J Investig Allergol Clin Immunol. 2020; 30(5): 346-57. https://doi.org/10.18176/jiaci.0595.

13. Agyeman AA, Chin KL, Landersdorfer $C B$ et al. Smell and taste dysfunction in patients with COVID-19: A systematic review and meta-analysis. Mayo Clin Proc. 2020; 95(8): 1621-31. https://doi.org/10.1016/j.mayocp.2020.05.030.

14. Saniasiaya J, Islam MA, Abdullah B. Prevalence of olfactory dysfunction in coronavirus disease 2019 (COVID-19): A metaanalysis of 27492 patients. Laryngoscope. 2020. https://doi. org/10.1002/lary.29286.

15. Amorim Dos Santos J, Normando AGC, Carvalho da Silva RL. Oral mucosal lesions in a COVID-19 patient: New signs or secondary manifestations? Int J Infect Dis. 2020; 97: 326-8. https://doi.org/10.1016/j.ijid.2020.06.012.

16. Fodoulian L, Tuberosa J, Rossier D et al. SARS-CoV-2 receptor and entry genes are expressed by sustentacular cells in the human olfactory neuroepithelium. BioRxiv. 2020. https://doi. org/10.1101/2020.03.31.013268.

17. Hopkins C, Lechien JR, Saussez S. More that ACE2? NRP1 may play a central role in the underlying pathophysiological mechanism of olfactory dysfunction in COVID-19 and its association with enhanced survival. Medical Hypotheses. 2020. https://doi.org/10.1016/j.mehy.2020.110406.

18. von Bartheld CS, Hagen MM, Butowtz R. Prevalence of Chemosensory Dysfunction in COVID-19 Patients: A Systematic Review and Meta-analysis Reveals Significant Ethnic Differences. ACS Chem Neurosci. 2020; 11(19): 2944-61. https:// doi.org/10.1021/acschemneuro.0c00460.

19. Hopkins $C$, Alanin M, Philpott $C$ et al. Management of new onset loss of sense of smell during the COVID-19 pandemic - BRS Consensus Guidelines. Clin Otolaryngol. 2020. https:// doi.org/10.1111/coa.1363.

ORCID

P. Rapiejko - ID - http://orcid.org/0000-0003-3868-0294

A. Lipiec - ID - http://orcid.org/0000-0003-3037-2326

Wkład autorów/Authors' contributions:

P. Rapiejko: 50\%; A. Lipiec: 50\%.

Konflikt interesów/Conflict of interests:

Nie występuje.

Finansowanie/Financial support:

Nie występuje.

Etyka/Ethics:

Treści przedstawione w artykule są zgodne z zasadami Deklaracji Helsińskiej, dyrektywami EU oraz ujednoliconymi wymaganiami dla czasopism biomedycznych. 
Copyright: (C) Medical Education sp. z 0.0. This is an Open Access article distributed under the terms of the Attribution-NonCommercial 4.0 International (CC BY-NC 4.0). License (https://creativecommons.org/licenses/by-nc/4.0/), allowing third parties to copy and redistribute the material in any medium or format and to remix, transform, and build upon the material, provided the original work is properly cited and states its license.
Adres do korespondencji

dr n med. Piotr Rapiejko

Klinika Otolaryngologii i Onkologii Laryngologicznej

z Klinicznym Oddziałem Chirurgii

Czaszkowo-Szczękowo-Twarzowej,

Wojskowy Instytut Medyczny

04-141 Warszawa, ul. Szaserów 128 